\title{
Glossary: Javanese and Old Javanese terms
}

\begin{tabular}{|c|c|}
\hline amerta & holy water \\
\hline Ardhanariswara & deity half-male and half-female \\
\hline brahmana/brahman & priest \\
\hline cakra & $\begin{array}{l}\text { node in the body along the vertical spine; an expression } \\
\text { within the Tantric scheme }\end{array}$ \\
\hline candi & temple \\
\hline \multirow[t]{2}{*}{ dharma } & (a) commemorative temple \\
\hline & (b) religious teaching \\
\hline dwarapala & gatekeeper, guardian figure in demonic form \\
\hline \multirow[t]{2}{*}{ granthi } & three nodes, forming obstacles in the ascent of the \\
\hline & Kundalini, in the body along the spine \\
\hline ishtadewata & personal protective deity of the individual being \\
\hline kadewaguruan & group of mountain sanctuaries and hermitages \\
\hline kadeyan & friend and companion of Panji \\
\hline kain & loincloth \\
\hline kala & monster head above temple entrances; god of the time \\
\hline kaliyuga & final period of the world before its destruction \\
\hline \multirow[t]{2}{*}{ kakawin } & poem in Old Javanese language with a metre based on \\
\hline & Indian lyrics \\
\hline karma & law of cause and effect; effects of all deeds \\
\hline karshyan & group of mountain sanctuaries and hermitages \\
\hline \multirow[t]{2}{*}{ kawi } & poet who composes a kakawin; also: Old Javanese script \\
\hline & and language \\
\hline kemben & breast cloth for women \\
\hline ketu & turban of hermits \\
\hline kidung & poem in Middle Javanese language \\
\hline kraton & palace of the king \\
\hline kshatriya & member of the ruling class in Hindu society \\
\hline Kundalini & serpent; a form of Sakti in the Tantric doctrine \\
\hline lakon & story plot of a shadow play \\
\hline langö & beauty; rapture caused by beauty \\
\hline
\end{tabular}




\begin{tabular}{|c|c|}
\hline lingga & the phallus of God Siwa \\
\hline \multirow[t]{2}{*}{ lontar } & writing material in ancient Java, a leaf from the lontar \\
\hline & plant \\
\hline makara & aquatic monster \\
\hline \multirow[t]{4}{*}{ mandala } & diagram, \\
\hline & (a) a certain structure of kingdoms \\
\hline & (b) a meditation object \\
\hline & (c) group of mountain sanctuaries and hermitages \\
\hline Meru & mythical mountain, the seat of the gods \\
\hline moksha & deliverance of the soul \\
\hline naga & serpent \\
\hline pendopo & open hall with pillars carrying the roof \\
\hline panakawan & $\begin{array}{l}\text { companion of the heroes, usually in deformed body } \\
\text { shape }\end{array}$ \\
\hline pemujaan & place of worship \\
\hline pertapaan & hermitage \\
\hline petirtaan & bathing place \\
\hline pradakshina & clockwise circumambulation \\
\hline prasareya & counterclockwise circumambulation \\
\hline puja & worshipping a god/ the gods \\
\hline pura & Balinese temple \\
\hline rakshasa & demon \\
\hline$r s h i$ & hermit \\
\hline sawah & wet-rice field \\
\hline sakti & magic/mystic power \\
\hline samsara & cycle of rebirths \\
\hline sima & royal grant, area freed from certain taxes \\
\hline sembah & $\begin{array}{l}\text { kneeling and folding the hands in front of a venerated } \\
\text { person }\end{array}$ \\
\hline sraddha & $\begin{array}{l}\text { ceremony held } 12 \text { years after the death of a royal } \\
\text { personage }\end{array}$ \\
\hline tekes & Javanese headgear, term used for the 'cap' \\
\hline tirtha & holy water, holy bathing place (Old Javanese for \\
\hline & 'petirtaan’) \\
\hline upawita & sacred caste cord worn by gods and hermits \\
\hline vina & $\begin{array}{l}\text { musical string-instrument with two gourds as sound } \\
\text { resonators }\end{array}$ \\
\hline wayang beber & performance of a story painted on long paper scrolls \\
\hline
\end{tabular}


wayang kulit

wayang topeng

widadari

yantra

yogin

yoni shadowplay with leather puppets

mask dance

heavenly nymph

a means in meditation, particularly in Tantric practice

pupil following the practice of yoga

the vagina of the Goddess Sakti/Prtiwi (the consort of Siwa) 